\title{
A Note from the President of the Gesellschaft für Wissenschaftsphilosophie
}

\author{
Gerhard Schurz ${ }^{1}$
}

Published online: 1 April 2019

(c) Springer Nature B.V. 2019

I am very happy to comply with the editors' request to write a few lines on the situation of philosophy of science, especially in Germany, on the occasion of the 50th JGPS anniversary, although this is not an easy task: Such a 'snapshot' inevitably has to make rather arbitrary choices; this has to be said ahead.

Philosophy of science is ultimately as old as the sciences themselves, so it has its beginnings in antiquity (Losee 1977). Although philosophy of science for good reasons never detached itself from philosophy in general, it attained a certain independence in the course of the twentieth century. Next to the anglo-saxon analytical philosophy (G. E. Moore, B. Russell and others) it was, as is well known, the logical empiricism of the Vienna Circle (M. Schlick, O. Neurath, R. Carnap and others) and of the Berlin Circle (H. Reichenbach, C. G. Hempel and others) as well as K. R. Popper's critical rationalism that contributed to the importance and profile of philosophy of science. Thus modern philosophy of science is also a product of philosophy in the German-speaking countries.

However, under the pressure of National Socialism, almost all philosophers of science were forced to emigrate. This is why the further development of philosophy of science around the middle of the twentieth century mainly took place in the USA. What later philosophy of science and logical empiricism still have in common is the high standards of conceptual and argumentative accuracy as well as the close connection to the current state of scientific research. The positivist and reductionist restrictions of the logical empiricism of the 1930s, however, were gradually discarded and replaced by positions to which the terms 'positivism' and 'empiricism' no longer applied.

This philosophy of science, sometimes labelled as a 'postpositivist' philosophy of science, was slowly gaining a foothold also in Europe during the post-war period. Wolfgang Stegmüller is the philosopher of science who probably deserves the greatest credit for reestablishing the discipline in the German-speaking world after the Second World War. In his monumental work Probleme und Resultate der Wissenschaftstheorie und Analytischen Philosophie (1969-1986, 4 volumes with numerous subvolumes) he transferred the AngloSaxon philosophy of science at that time into the German-speaking world by excellent representations and interpretations. Also the term 'Wissenschaftstheorie' itself was made popular by Wolfgang Stegmüller in the middle of the twentieth century (cf. Essler et al. 2000, 18, fn. 2).

Gerhard Schurz

schurz@phil.uni-duesseldorf.de

1 Institut für Philosophie, Heinrich Heine Universität Düsseldorf, 40225 Düsseldorf, Germany 
In addition to Wolfgang Stegmüller, Paul Lorenzen, Alwin Diemer, Erhard Scheibe and Lorenz Krüger also contributed significantly to the early rehabilitation of philosophy of science in Germany. This list could be extended at will. Central for the further development was, of course, also to found or continue independent journals of philosophy of science based in Germany. Three important journals on philosophy of science have been published in the German-speaking world after the Second World War: Philosophia Naturalis (founded in 1950 by E. May, published until 2013), Zeitschrift für Allgemeine Wissenschaftstheorie-Journal for General Philosophy of Science (today with reversed titles; founded in 1970 by A. Diemer, L. Geldsetzer and G. König) and the journal Erkenntnis (founded by the Vienna Circle in 1930, from 1975 onwards continued by W. K. Essler, C. Hempel and W. Stegmüller). According to a study carried out in 2013 by Unterhuber et al. (2014), their shares among German-based journal publications amounted to $23.4 \%$ for JGPS, $18 \%$ for Philosophia Naturalis and $14.4 \%$ for Erkenntnis.

Summing up, it can be said that philosophy of science has enjoyed a continuing upswing in the German-speaking world since the 1970s, both in terms of content and of scope. Compared to that time, modern philosophy of science is much less school-oriented: Schools like the Erlangen-Konstanz group of contructivism or the Munich school of structuralism are less important today. In return, the diversity of areas of research in philosophy of science has become more extensive and, at the same time, philosophy of science has become more independent and pluralistic. Today, philosophy of science is one of the most active parts of academic philosophy. Through its close connection with other scientific disciplines, it contributes significantly to the interdisciplinary relevance of philosophy. This is also supported by the fact that philosophy of science is not only part of philosophy, but also practiced in other scientific disciplines.

Philosophy of science also plays an important role in the broader public. Two points of its relevance for the society should be particularly highlighted:

(1) The demarcation problem of philosophy of science: From a social point of view, it has to be asked which parts of our ideas may claim the status of objective knowledge and may be taught in public schools. This does not apply to subjective values, ideologies or religious convictions. This problem became shattering, for example, in the confrontation with creationism (Schurz 2014, 3).

(2) The enlightening function of philosophy of science: It is important to counteract the risk of ideological misuse of science and its results. This task is perhaps more important than ever in the current political situation of many states.

In 2018, philosophy of science was included in the official list of 'small subjects'. This list is maintained by the 'Small Subjects Office' (located at the University of Mainz and supported by the Federal Ministry of Education and Research) and presented on the Internet. Currently, this list includes 151 small subjects, ranging from general linguistics and biophysics to philosophy of science (https://www.kleinefaecher.de/beiträge). According to a list compiled by the Gesellschaft für Wissenschaftsphilosophie in 2013, there are now well over 30 professorships for philosophy of science in Germany, although not all of them are denominated as 'philosophy of science' ('Wissenschaftsphilosophie', resp. 'Wissenschaftstheorie'). According to the 'Small Subjects Office' there are currently at least 28 professorships in philosophy of science.

The growth of the German-language philosophy of science has meanwhile also resulted in the founding of an independent association, the Gesellschaft für 
Wissenschaftsphilosophie (German Society for Philosophy of Science), in short GWP. The society was founded in 2011 by a group of philosophers of science due to the driving force of Holger Lyre, who also became its first president. The GWP holds conferences every 3 years. The first one took place in 2013 in Hannover, the second one was held in 2016 in Düsseldorf, and the third one took place recently in Cologne. The number of members of the young society is now about to exceed the mark 200; even more widespread is the GWPNewsletter (not yet linked to membership).

The GWP maintains a sustainable cooperation with the Journal for General Philosophy of Science (JGPS). This is underscored by the regular cooptation of a member of the Editorial Board of JGPS to the Board of GWP. Currently, Thomas Reydon holds this position. Members of GWP have free electronic access to JGPS via the members area on the GWPwebsite; they can also obtain the print version at a reduced price of 50 Euros per year. In addition, the $G W P$ regularly cooperates with related scientific societies, in particular by holding joint workshops and symposia. It is also a member of higher-level umbrella associations (member of EPSA since 2013 and DLMPST-candidate since 2018).

As mentioned earlier, current philosophy of science is subdivided into a number of special areas whose current research shares can best be derived from the statistics of the submission of contributions to the latest GWP-conference (GWP.2019), which took place February 25-27 this year in Cologne:

- General Philosophy of Science: 51\% (Causality and Mechanisms: 9\%, Models: 8\%, Explanation: $8 \%$, Values in Science: 9\%, Other: 17\%)

- Philosophy of Physics: $12 \%$

- Philosophy of Life Sciences: $16 \%$

- Philosophy of the Social Sciences, Humanities, Cognition: $13 \%$

- History of Philosophy of Science: $8 \%$.

This distribution among the sub-areas of philosophy of science reflects the broad as well as balanced spectrum of interests of the submitted contributions, whose total number of 170 was pleasingly high.

\section{References}

Essler, W., Labude, J., \& Ucsnay, S. (2000). Theorie und Erfahrung. Freiburg: Karl Alber.

Losee, J. (1977). Wissenschaftstheorie. Eine historische Einführung. C.H. Beck, München: C. H. Beck (engl. Orig. 1972).

Schurz, G. (2014). Philosophy of science: A unified approach. New York: Routledge.

Unterhuber, M., Gebharter, A., \& Schurz, G. (2014). Philosophy of science in Germany, 1992-2012: Survey-based overview and quantitative analysis. Journal for General Philosophy of Science, 45 (Supplement), 71-160.

Publisher's Note Springer Nature remains neutral with regard to jurisdictional claims in published maps and institutional affiliations. 